GOSPODARKA SUROWCAMI MINERALNYMI - MINERAL RESOURCES MANAGEMENT

\title{
Badanie wpływu domieszek żelaza na parametry barwy kopalin skaleniowo-kwarcowych po wypaleniu
}

\section{Wprowadzenie}

Cechy optyczne, takie jak jasność i barwa surowców mineralnych wykorzystywanych w przemyśle ceramicznym mają zasadnicze znaczenie dla uzyskania pożądanego efektu kolorystycznego produkowanych z nich wyrobów. Podstawę współczesnych systemów diagnostyki barw stanowi stosowany powszechnie do opisu tych parametrów model CIE L*a*b* (rys. 1). Model ten opiera się na kolorach przeciwstawnych. Wartość „L” odnosi się do jasności próbki i mieści się w przedziale od 0\% (absolutna czerń) do 100\% (idealna biel), wartość „a” odpowiada barwie czerwonej (a>0) lub zielonej $(\mathrm{a}<0)$, a wartość „,b” - barwie żółtej (b > 0) lub niebieskiej (b < 0) (Mielicki 1997).

Przyczyną zróżnicowania barw minerałów jest selektywne pochłanianie przez nie światła o różnej długości fali w zakresie widzialnej części promieniowania elektromagnetycznego. Wiadomo, że istotny wpływ na barwę minerału lub tworzywa ceramicznego ma obecność domieszek żelaza, która w znacznym stopniu obniża ich jasność/białość, nadając im czerwono-brunatny względnie zielony odcień w zależności od stopnia utlenienia jonu tego pierwiastka, jego pozycji w strukturze minerału i liczby koordynacyjnej (Sikora 1974; Hogg i Noble 1979; Bolewski i in. 1991). Często barwa minerałów spowodowana jest obecnością w ich strukturze jonów metali przejściowych, do których, oprócz Fe, należą: Ti, V, Cr,

\footnotetext{
* Dr inż., Instytut Gospodarki Surowcami Mineralnymi i Energią PAN, Zakład Badań Rynku Surowcowego
} i Energetycznego, Kraków; e-mail: lewicka@min-pan.krakow.pl 


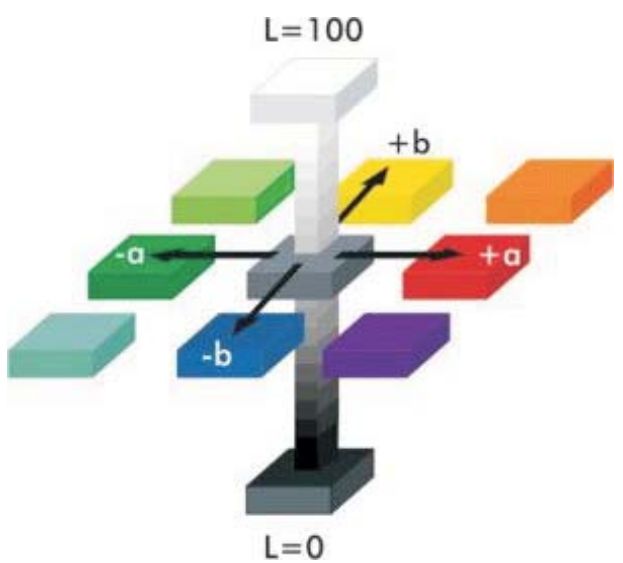

Rys. 1. Schemat budowy modelu CIE L*a*b* (Mielicki 1997)

Fig. 1. Schematic diagram of the CIE L*a*b* model (Mielicki 1997)

$\mathrm{Mn}, \mathrm{Co}, \mathrm{Ni}$ i $\mathrm{Cu}$, lub pierwiastków ziem rzadkich. Mogą one stanowić jeden z głównych składników chemicznych minerału lub wchodzić w jego strukturę jako domieszka izomorficzna (Sikora 1974). Jony te mają zdolność selektywnej absorpcji światła widzialnego, która jest związana z przejściami między różnymi stanami energetycznymi elektronów. Im większa jest ilość tych domieszek, tym absorpcja jest silniejsza.

Niniejszy artykuł omawia wyniki badań stosowanych powszechnie w krajowym przemyśle ceramicznym surowców skaleniowo-kwarcowych z czterech złóż granitoidów eksploatowanych w rejonie Sobótki (Pagórki Zachodnie, Pagórki Wschodnie, Strzeblów I i Stary Łom). Przeprowadzono je w celu identyfikacji minerałów, będących nośnikami głównie żelaza, ale i innych pierwiastków barwiących, oraz stwierdzenia korelacji między ich zawartością a cechami optycznymi próbek tych kopalin po wypaleniu. Przedstawione w niniejszym opracowaniu badania stanowią kontynuację wcześniejszych prac (Lewicka 2013), których rezultaty sugerowały potrzebę oznaczenia w próbkach innych niż żelazo i tytan pierwiastków barwiących, zwłaszcza Mn, REE, $\mathrm{U}, \mathrm{Th}, \mathrm{Pb}$, oraz metali przejściowych, w celu właściwej interpretacji zróżnicowania barwy próbek tych kopalin po wypaleniu. Potrzebę taką uzasadniały znane właściwości barwiące wymienionych pierwiastków. Przykładowo związki manganu mogą powodować fioletowe, brązowe lub czarne, ale także różowe, pomarańczowe czy żółte zabarwienie, domieszka ceru - jasnoniebieskie lub żółte, prazeodymu - zielone, neodymu - różowoczerwone, a toru i uranu czarne, żółte bądź pomarańczowe (Sikora 1974; Nassau 1978; Hogg i Noble 1979; Bolewski i in. 1991).

Obserwacje przyrodnicze są coraz częściej wykorzystywane do syntezy rozmaitych pigmentów, zwłaszcza ceramicznych, które na ogół stanowią odwzorowanie struktury minerałów grupy granatu oraz cyrkonu $\mathrm{Zr}\left[\mathrm{SiO}_{4}\right]$ (Dziubak 2012). 


\section{Podsumowanie badań z lat 2011-2012}

Na podstawie badań wykonanych w latach 2011-2012, które obejmowały: obserwacje mikroskopowe w świetle przechodzącym, analizy chemiczne w zakresie składników głównych oraz badania scanningowe SEM-EDS stwierdzono, że głównymi nośnikami żelaza w próbkach analizowanych skał są minerały, w których stanowi ono domieszkę izomorficzna, a tylko podrzędnie - jego minerały własne (tab. 1, Lewicka 2013; Lewicka i Franus 2014).

Tabela 1. Fazy mineralne żelaza zidentyfikowane metodą mikroskopii optycznej i skaningowej (SEM-EDS) w próbkach kopaliny skaleniowo-kwarcowej ze złóż w rejonie Sobótki

Table 1. Ferruginous phases identified by optical and scanning (SEM-EDS) microscopy in samples of feldspar-quartz raw materials from deposits in the Sobótka region

\begin{tabular}{|c|c|c|}
\hline Nazwa złoża & Minerały własne Fe & Nośniki Fe w strukturze minerału \\
\hline Pagórki Zachodnie (PZ) & piryt, hematyt & $\begin{array}{l}\text { muskowit, biotyt, serycyt, rutyl, monacyt, } \\
\text { ksenotym, cyrkon }\end{array}$ \\
\hline Pagórki Wschodnie (PW) & piryt & biotyt, rutyl, muskowit, granaty, epidot, chloryt \\
\hline Strzeblów I (SI) & piryt, tytanomagnetyt & $\begin{array}{l}\text { serycyt, biotyt, rutyl, muskowit, granat, cyrkon, } \\
\text { chloryt, epidot (pistacyt), monacyt }\end{array}$ \\
\hline Stary Łom (SL) & & $\begin{array}{l}\text { muskowit, serycyt, chloryt, granaty, epidot, } \\
\text { cyrkon, monacyt }\end{array}$ \\
\hline
\end{tabular}

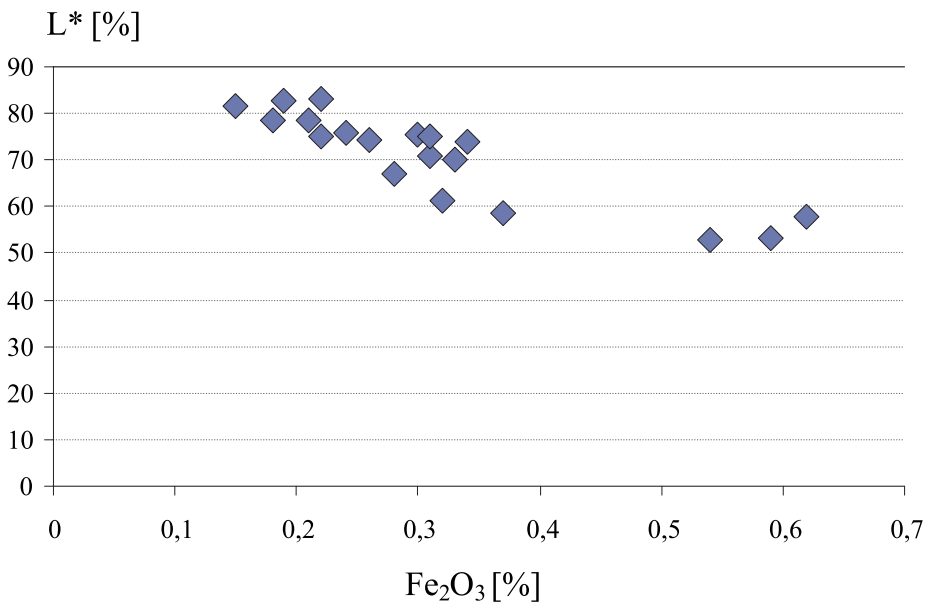

Rys. 2. Zawartość $\mathrm{Fe}_{2} \mathrm{O}_{3}$ a jasność próbek kopaliny skaleniowo-kwarcowej po wypaleniu

Fig. 2. Content of $\mathrm{Fe}_{2} \mathrm{O}_{3}$ versus brightnes of feldspar-quartz raw material samples after firing 
Oznaczenia parametrów barwy próbek kopalin po wypaleniu w $1200^{\circ} \mathrm{C}$ wykonane w układzie L*a*b* metodą spektrofotometryczną wykazały znaczne zróżnicowanie tych parametrów (Lewicka 2013). Szczególną uwagę zwrócił odmienny odcień, nasycenie barwy i jasność próbek o zbliżonej zawartości $\mathrm{Fe}_{2} \mathrm{O}_{3} \mathrm{i} \mathrm{TiO}_{2}$. Wartość parametrów „L” i „a” wiązano z zawartością $\mathrm{Fe}_{2} \mathrm{O}_{3}$ w próbkach. Generalnie, im była ona wyższa, tym niższa była jasność próbki (rys. 2), a wyższa wartość „a” związana z nasyceniem barwy czerwonej, względnie czerwono-brązowej (rys. 3). Odstępstwo od tej reguły zaobserwowano dla próbek o największym udziale $\mathrm{Fe}_{2} \mathrm{O}_{3}$ (odpowiednio 0,54; 0,59 i 0,62\%), dla których wartość „„a” była

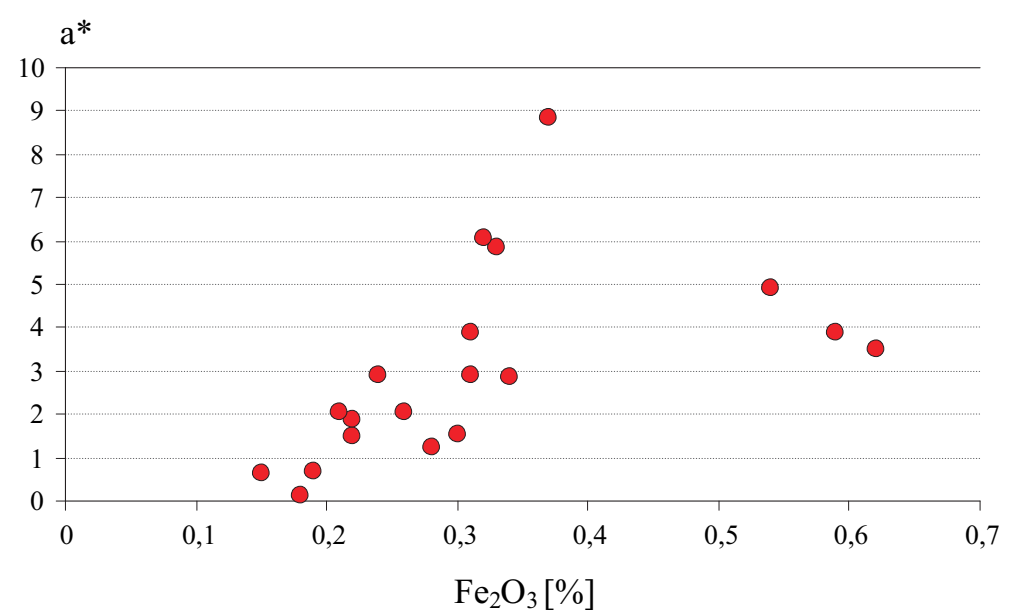

Rys. 3. Zawartość $\mathrm{Fe}_{2} \mathrm{O}_{3}$ a parametr a* kopaliny skaleniowo-kwarcowej po wypaleniu

Fig. 3. Content of $\mathrm{Fe}_{2} \mathrm{O}_{3}$ versus a* parameter of feldspar-quartz raw material samples after firing

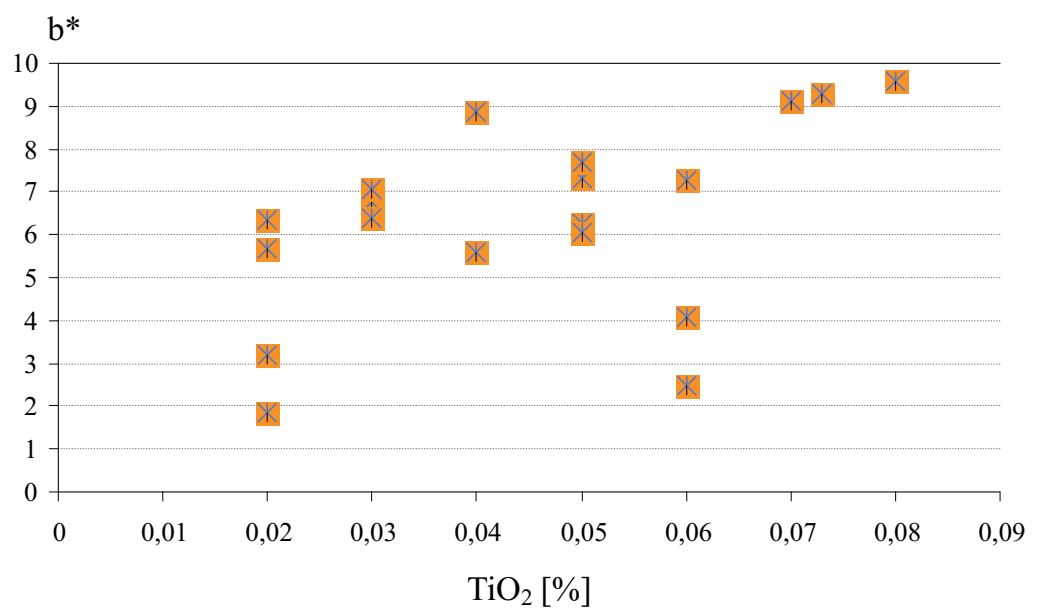

Rys. 4. Zawartość tlenku tytanu a parametr b* próbek kopaliny skaleniowo-kwarcowej po wypaleniu

Fig. 4. Content of $\mathrm{TiO}_{2}$ versus b* parameter of feldspar-quartz raw material samples after firing 
znacznie niższa niż dla próbki z $0,37 \% \mathrm{Fe}_{2} \mathrm{O}_{3}$, dla której uzyskano jej maksimum $(\mathrm{a}=8,86)$, co może nasuwać przypuszczenie, że tylko część obecnego w tych próbkach żelaza wywołała efekt barwny. Również jasność próbek o tym samym udziale $\mathrm{Fe}_{2} \mathrm{O}_{3}$ była odmienna. Wartość parametru „b” wiązano głównie z udziałem $\mathrm{TiO}_{2}$ (odpowiedzialnego za odcień żółty), choć w tym przypadku korelacja była znacznie słabsza niż obserwowana dla $\mathrm{Fe}_{2} \mathrm{O}_{3}$ i parametru „„" (rys. 4). Stwierdzono natomiast, że zawartość tego tlenku nie ma wpływu na jasność próbki (rys. 5). Wobec powyższego uznano, że różne zabarwienie po wypaleniu próbek o zbliżonym udziale wymienionych tlenków wskazuje na możliwy wpływ innych pierwiastków barwiących na uzyskany efekt kolorystyczny, tj. m.in.: Mn, REE, Pb, Th, U i innych. Ich obecność w strukturze składników mineralnych (granaty, rutyl, apatyt, epidot, monacyt, cyrkon, biotyt - w znacznym stopniu schlorytyzowany i chloryt) analizowanych skał wykazały przeprowadzone wcześniej badania SEM-EDS (Lewicka 2013). W celu potwierdzenia tej hipotezy dla wytypowanych próbek wykonano dodatkowe obserwacje mikroskopowe, a także pełną analizę składu chemicznego na zawartość składników głównych, podrzędnych i śladowych.

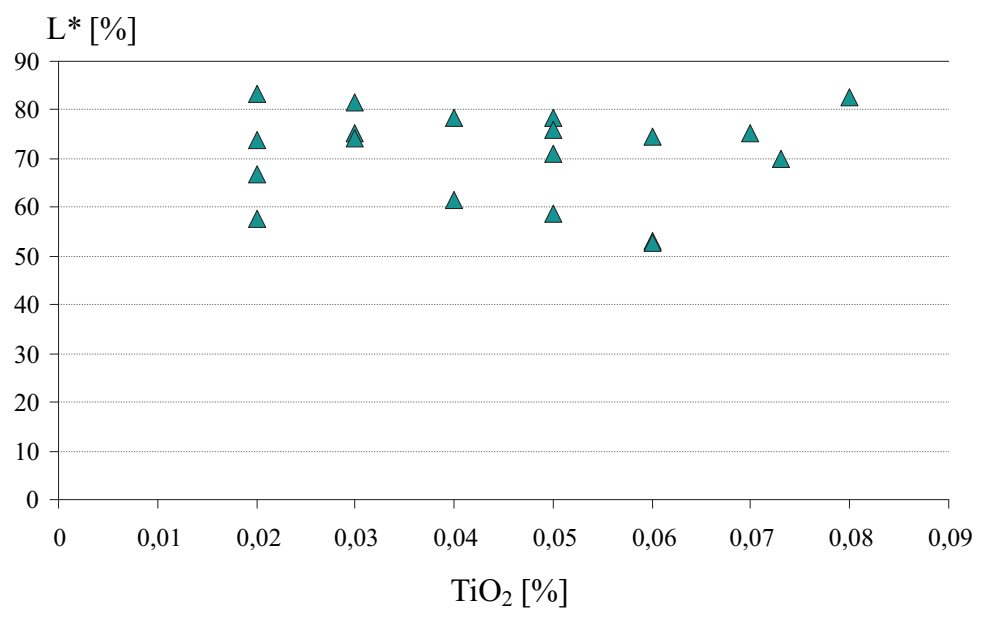

Rys. 5. Zawartość tlenku tytanu a jasność próbek kopaliny skaleniowo-kwarcowej po wypaleniu

Fig. 5. Content of $\mathrm{TiO}_{2}$ versus $b^{*}$ parameter of feldspar-quartz raw material samples after firing

\section{Badania metodą mikroskopii scanningowej SEM-EDS}

Badania SEM-EDS wykonano przy użyciu mikroskopu scanningowego z zimną emisją polową FEI Quanta FEG, wyposażonego w system analizy składu chemicznego oparty na dyspersji energii promieniowania rentgenowskiego firmy EDAX. Próbki napylono stopem $\mathrm{Au} / \mathrm{Pd}$. 
Wyniki obserwacji mikroskopowych i pomiarów składu chemicznego w mikroobszarze wykazały obecność obok minerałów własnych żelaza (głównie pirytu, rys. 6), również licznych jego nośników, takich jak:

- granaty żelazowo-manganowe z udziałem $27-48 \% \mathrm{Fe}_{2} \mathrm{O}_{3} \mathrm{i} 12-16 \% \mathrm{MnO}$ (rys. 7),

- biotyt, w znacznym stopniu schlorytyzowany, z $38-67 \% \mathrm{Fe}_{2} \mathrm{O}_{3}$ i $2-3 \% \mathrm{MnO}$ (rys. 6-7, 12),

- monacyt wysokotorowy, w którym udział $\mathrm{ThO}_{2}$ sięgał 22\%, a Ce $\mathrm{O}_{3}-39 \%$ (rys. 8),

- cyrkon, często z wrostkami faz żelazistych (do 61\% $\mathrm{Fe}_{2} \mathrm{O}_{3}$ ) (rys. 9-10),

- galena z domieszką do $7 \% \mathrm{Fe}_{2} \mathrm{O}_{3}$ i $3 \% \mathrm{MnO}$ (rys. 11),

- rutyl z $1,5 \% \mathrm{Fe}_{2} \mathrm{O}_{3}$ i $1-2 \% \mathrm{MnO}$.
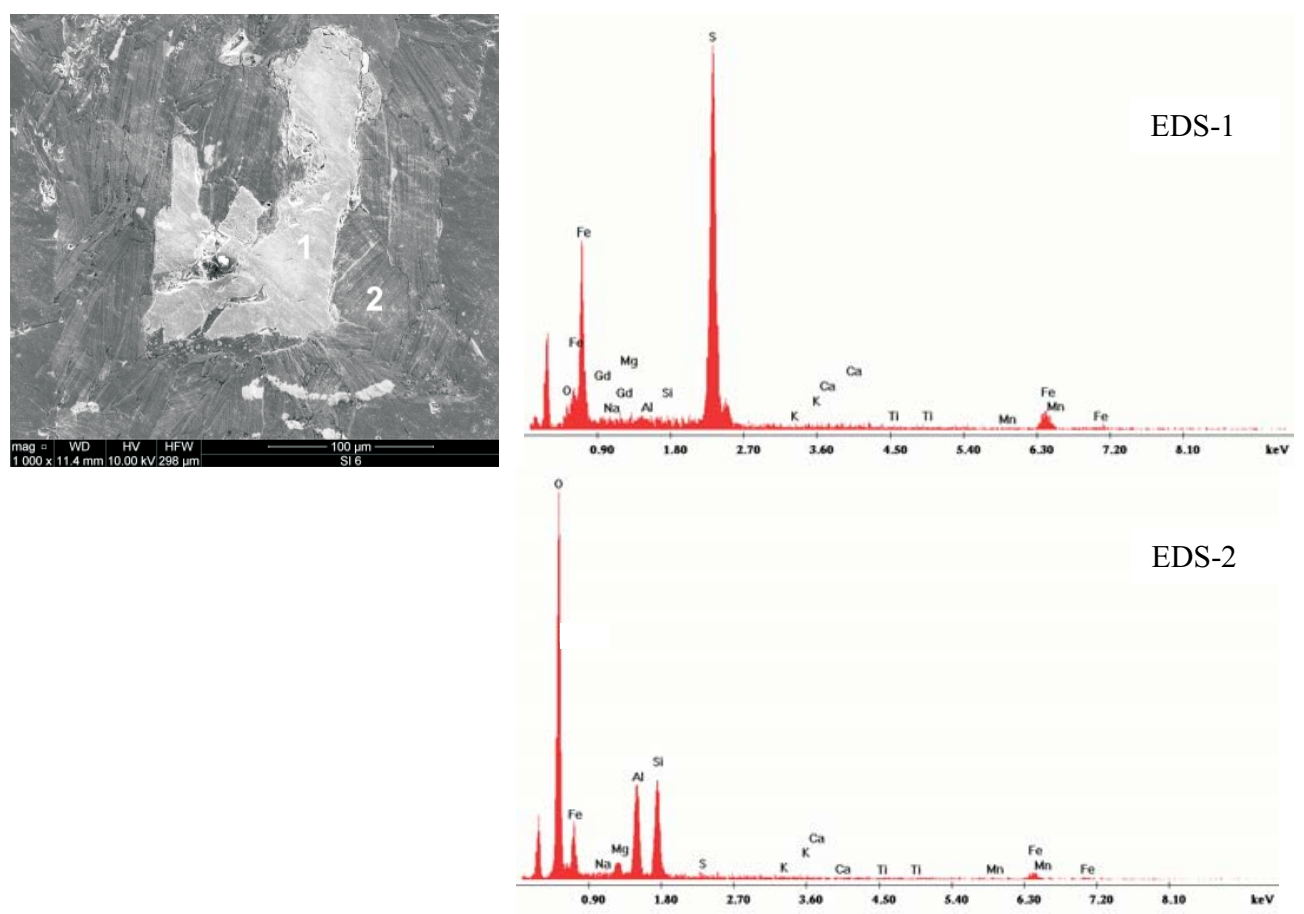

Rys. 6. Piryt (EDS-1) i schlorytyzowany biotyt (EDS-2)

w skale skaleniowo-kwarcowej ze złoża Strzeblów I

Fig. 6. Pyrite (EDS-1) and choritized biotite (EDS-2) in feldspar-quartz rock from Strzeblów I deposit 

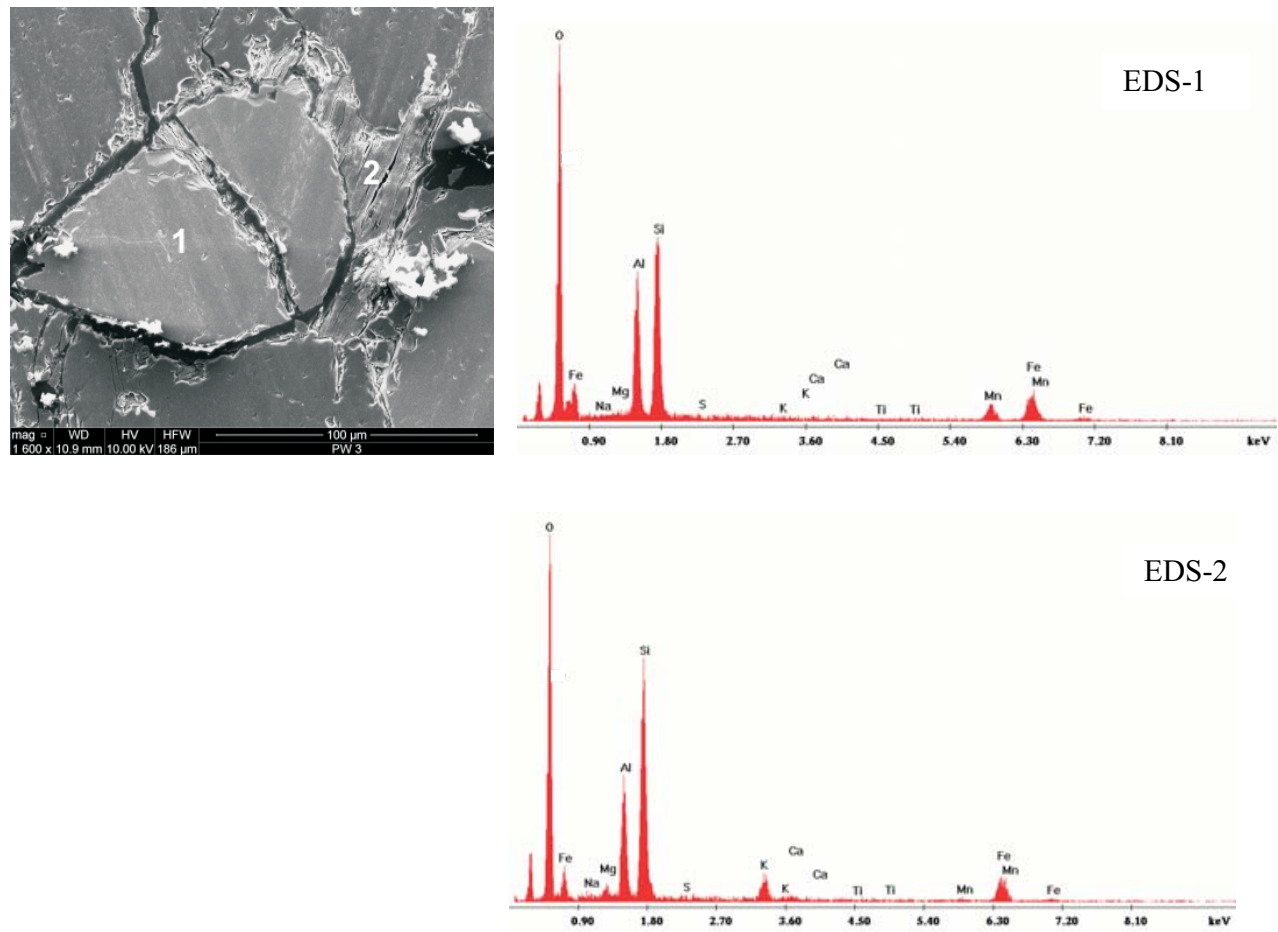

Rys. 7. Granat żelazowo-manganowy (EDS-1), obok schlorytyzowany biotyt (EDS-2) w skale skaleniowo-kwarcowej ze złoża Pagórki Wschodnie

Fig. 7. Fe-Mn garnet (EDS-1), next to chloritized biotite (EDS-2) in feldspar-quartz rock from Pagórki Wschodnie deposit
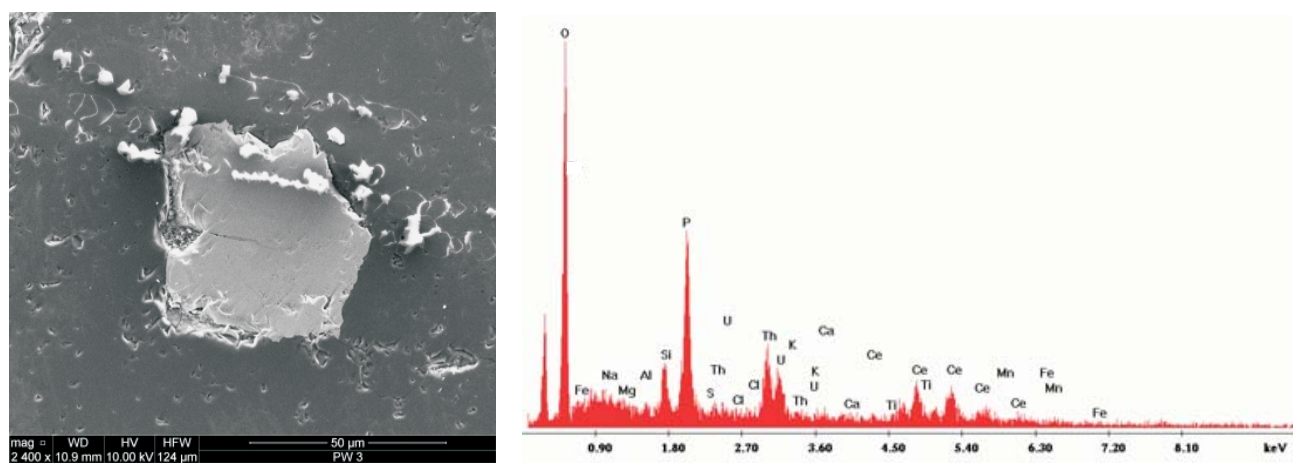

Rys. 8. Monacyt wysokotorowy w skale skaleniowo-kwarcowej ze złoża Pagórki Wschodnie

Fig. 8. Thrich, monazite in feldspar-quartz rock from Pagórki Wschodnie deposit 

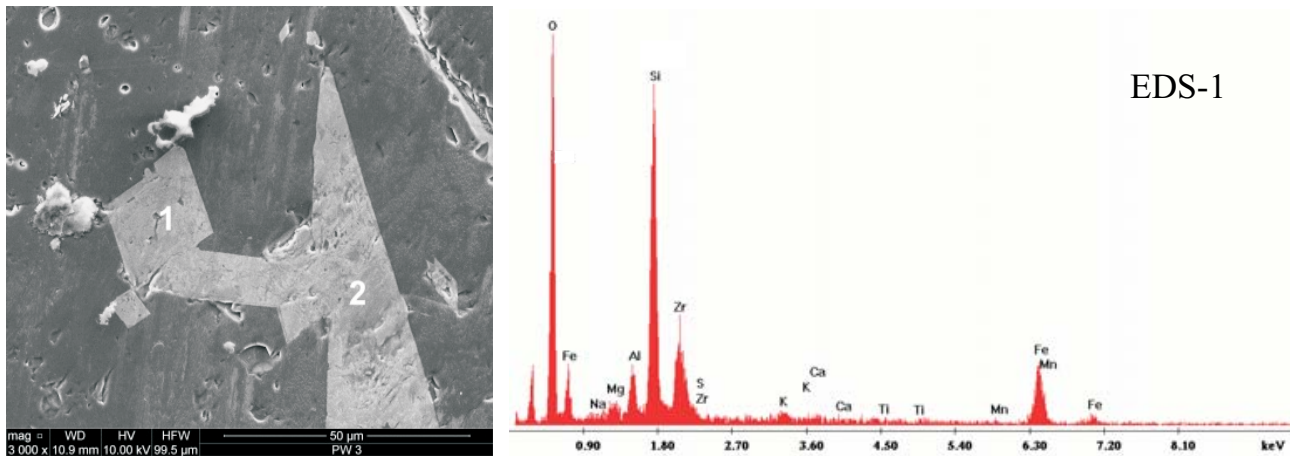

Rys. 9. Cyrkon (EDS-1) w skale skaleniowo-kwarcowej ze złoża Pagórki Wschodnie

Fig. 9. Zircon (EDS-1) in feldspar-quartz rock from Pagórki Wschodnie deposit
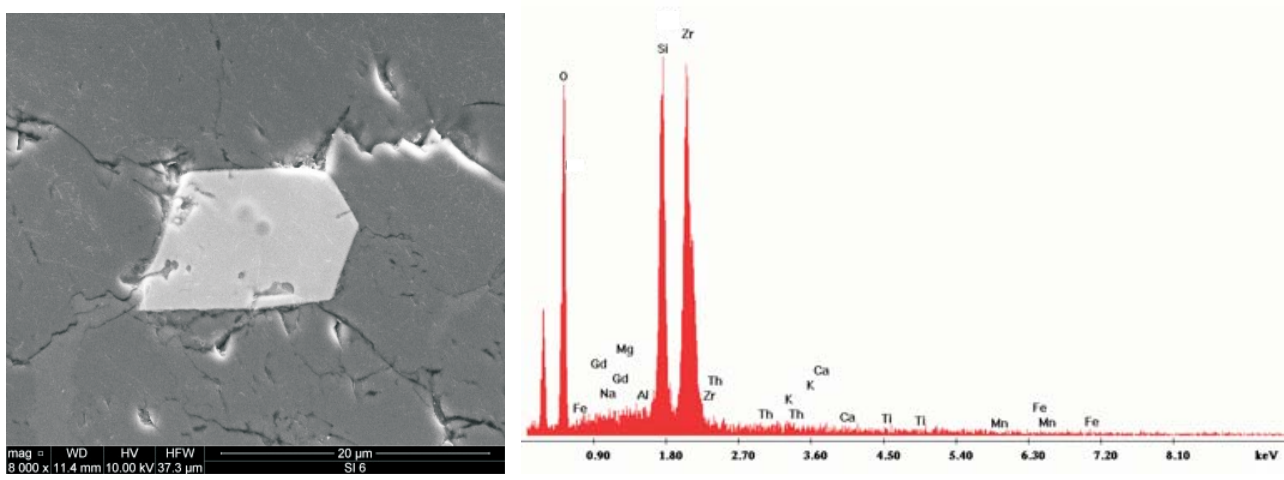

Rys. 10. Cyrkon w skale skaleniowo-kwarcowej ze złoża Strzeblów I

Fig. 10. Zircon (EDS-1) in feldspar-quartz rock from Strzeblów I deposit
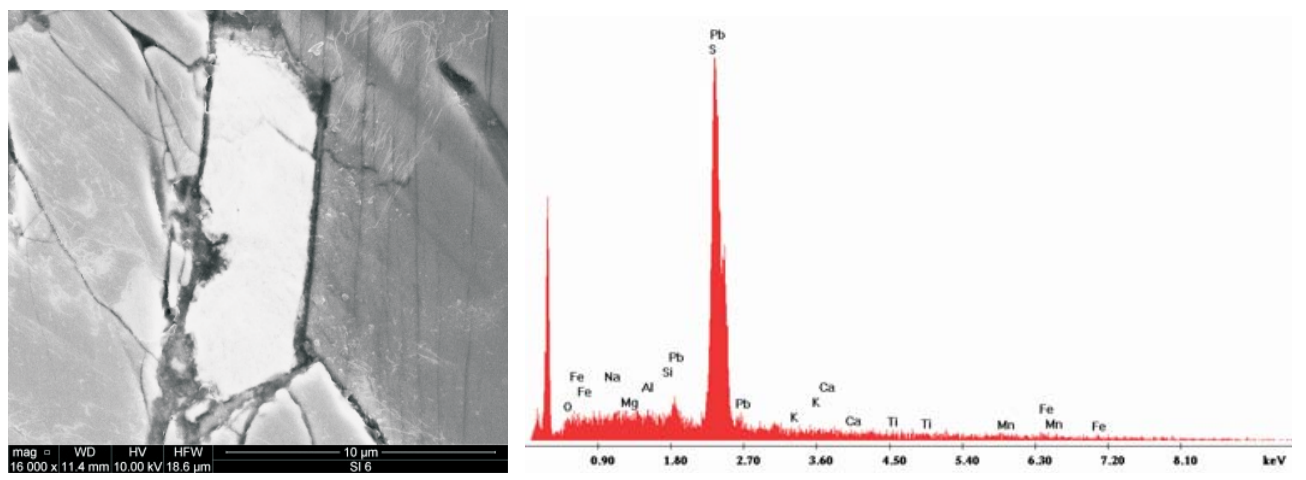

Rys. 11. Galena w skale skaleniowo-kwarcowej ze złoża Strzeblów I

Fig. 11. Galena (EDS-1) in feldspar-quartz rock from Strzeblów I deposit 

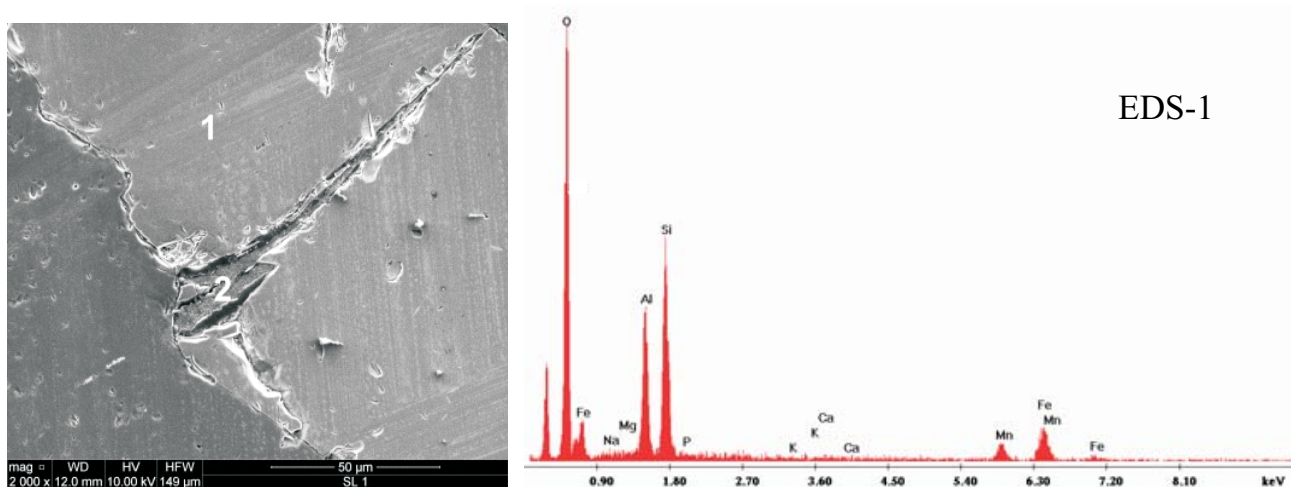

Rys. 12. Schlorytyzowany biotyt (EDS-1) w skale skaleniowo-kwarcowej ze złoża Stary Łom

Fig. 12. Chloritized biotite (EDS-1) in feldspar-quartz rock from Stary Łom deposit

\section{Analizy chemiczne na zawartość pierwiastków głównych i śladowych}

Analizy chemiczne wykonało Activation Laboratories - ACTALBS w Ancaster (Ontario, Kanada), przy użyciu metod spektrometrycznych ze wzbudzeniem plazmowym FUS-ICP (fusion - inductively coupled plasma) i TD-ICP (total digestion - inductively coupled plasma) oraz metodą instrumentalnej neutronowej analizy aktywacyjnej INAA (instrumental neutron activation analysis).

Do przeprowadzenia pełnej analizy chemicznej wytypowano 6 spośród 19 wcześniej badanych próbek. Kryterium ich wyboru stanowiła oznaczona wówczas, zbliżona lub jednakowa zawartość $\mathrm{Fe}_{2} \mathrm{O}_{3}$, przy równoczesnej wyraźnej odmienności zabarwienia próbek po wypaleniu (rys. 13). Były to próbki: PZ-2, PW-1 i SI-8, w których udział $\mathrm{Fe}_{2} \mathrm{O}_{3}$ wynosił $0,30-0,31 \%$ oraz PW-4, SI-4 i SL-2 z 0,24-0,25\% $\mathrm{Fe}_{2} \mathrm{O}_{3}$ (Lewicka 2013). Ponowna analiza chemiczna wniosła pewną korektę składu tlenkowego badanych próbek, głównie ze względu na zawartość $\mathrm{Fe}_{2} \mathrm{O}_{3}$, oznaczoną w ilości $0,33 \%$ w próbce PZ-2 oraz $0,30-0,31 \%$ w próbkach PW-1, SI-4 i SI-8, a poniżej 0,30\% - w próbkach PW-4 i SL-2 (tab. 2).

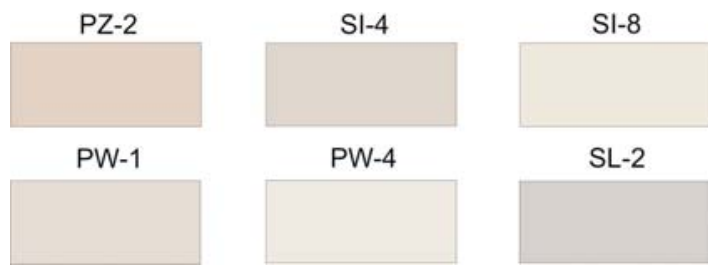

Fig. 13. Odcienie próbek wytypowanych do pełnej analizy chemicznej, według palety $\mathrm{L}^{*} \mathrm{a}^{*} \mathrm{~b}^{*}$

Fig. 13. Tinge of samples selected for full chemical analysis, acc. to $L^{*} a^{*} b^{*}$ palette 
Tabela 2. Skład chemiczny wybranych próbek kopaliny skaleniowo-kwarcowej ze złóż: Pagórki Zachodnie (PZ), Pagórki Wschodnie (PW), Strzeblów (SI) i Stary Łom (SL)

Table 2. Chemical composition of selected samples from Pagórki Zachodnie (PZ), Pagórki Wschodnie (PW), Strzeblów (SI), and Stary Łom (SL) deposits

\begin{tabular}{|c|c|c|c|c|c|c|c|}
\hline Składnik [\%] & Próg wykrywalności & PZ-2 & PW-1 & SI-8 & PW-4 & SI-4 & SL-2 \\
\hline $\mathrm{SiO}_{2}$ & $0,01 \%$ & 75,85 & 77,08 & 77,22 & 75,40 & 77,33 & 75,15 \\
\hline $\mathrm{Al}_{2} \mathrm{O}_{3}$ & $0,01 \%$ & 13,10 & 13,02 & 13,47 & 14,05 & 14,12 & 14,08 \\
\hline $\mathrm{Fe}_{2} \mathrm{O}_{3}$ całk. & $0,01 \%$ & 0,33 & 0,30 & 0,31 & 0,22 & 0,31 & 0,28 \\
\hline $\mathrm{TiO}_{2}$ & $0,005 \%$ & 0,07 & 0,03 & 0,07 & 0,02 & 0,05 & 0,02 \\
\hline $\mathrm{CaO}$ & $0,01 \%$ & 0,13 & 0,27 & 0,39 & 0,16 & 0,45 & 0,40 \\
\hline $\mathrm{MgO}$ & $0,01 \%$ & 0,06 & 0,05 & 0,05 & 0,05 & 0,03 & 0,02 \\
\hline $\mathrm{Na}_{2} \mathrm{O}$ & $0,01 \%$ & 3,47 & 3,77 & 3,76 & 3,92 & 4,26 & 4,79 \\
\hline $\mathrm{K}_{2} \mathrm{O}$ & $0,01 \%$ & 4,93 & 4,33 & 4,53 & 4,73 & 4,68 & 3,99 \\
\hline $\mathrm{MnO}$ & $0,01 \%$ & $<0,01$ & 0,02 & $<0,01$ & $<0,01$ & $<0,01$ & 0,03 \\
\hline $\mathrm{P}_{2} \mathrm{O}_{5}$ & $0,01 \%$ & $<0,01$ & $<0,01$ & 0,02 & 0,02 & $<0,01$ & $<0,01$ \\
\hline Strata prażenia & & 0,78 & 0,89 & 0,84 & 1,32 & 0,79 & 0,72 \\
\hline $\mathrm{Au}[\mathrm{ppb}]$ & $5 \mathrm{ppb}$ & $<5$ & $<5$ & 11 & $<5$ & $<5$ & $<5$ \\
\hline $\mathrm{Cu}[\mathrm{ppm}]$ & $1 \mathrm{ppm}$ & 3 & 3 & 2 & 3 & 15 & 3 \\
\hline $\mathrm{Ni}[\mathrm{ppm}]$ & $1 \mathrm{ppm}$ & $<1$ & 1 & 2 & $<1$ & $<1$ & 1 \\
\hline $\mathrm{Pb}[\mathrm{ppm}]$ & $5 \mathrm{ppm}$ & 26 & 26 & 24 & 19 & 34 & 28 \\
\hline Sc [ppm] & $0,1 \mathrm{ppm}$ & 3 & 4 & 3 & 6 & 3 & 5 \\
\hline Th [ppm] & $0,5 \mathrm{ppm}$ & 13 & 15 & 22 & 14 & 22 & 18 \\
\hline $\mathrm{U}[\mathrm{ppm}]$ & $0,5 \mathrm{ppm}$ & 2 & 2 & 5 & 2 & 2 & 3 \\
\hline $\mathrm{V}$ [ppm] & $5 \mathrm{ppm}$ & 10 & 7 & 9 & 9 & 6 & $<5$ \\
\hline $\mathrm{Zr}[\mathrm{ppm}]$ & $2 \mathrm{ppm}$ & 47 & 37 & 57 & 33 & 47 & 39 \\
\hline $\mathrm{Ce}[\mathrm{ppm}]$ & $3 \mathrm{ppm}$ & 40 & 27 & 29 & 21 & 29 & 18 \\
\hline $\mathrm{Nd}$ [ppm] & $5 \mathrm{ppm}$ & 24 & $<5$ & 18 & 9 & 14 & 16 \\
\hline
\end{tabular}

Wyniki pełnej analizy chemicznej wymienionych próbek tylko w przypadku dwóch z nich (PW-1 i SL-2) wykazały udział MnO nieznacznie powyżej progu wykrywalności, wynoszącego 0,01\% (tab. 2). Warto jednak zauważyć, że wizualnie próbka SL-2 (z 0,03\% MnO i $0,28 \% \mathrm{Fe}_{2} \mathrm{O}_{3}$ ) jest subiektywnie najciemniejsza (ma najniższą jasność) i najbardziej szara spośród nich. Znikome, bądź zmieniające się w stosunkowo niewielkim zakresie, okazały się również zawartości takich pierwiastków, jak Au (większość poniżej progu wykrywalności 5 ppb), Cr i Co (poniżej progu detekcji 1 ppm), Pb, Th, U oraz metali przejściowych (obok Ti, Fe, Mn, Cr, Co, również Sc, V, Ni i Cu), których podwyższona zawartość mogłaby powodować zróżnicowanie zabarwienia próbek. Jedynie w przypadku próbki PZ-2 jej nieco cieplejszy, czerwonawo-brązowy odcień może być związany z wyższą niż w pozostałych zawartością Ce i Nd, a także relatywnie największym udziałem $\mathrm{Fe}_{2} \mathrm{O}_{3}$ i $\mathrm{TiO}_{2}$. 


\section{Dyskusja wyników badań i wnioski}

Przeprowadzone badania wykazały, że żelazo w badanych próbkach skał skaleniowo-kwarcowych występuje jako jeden z głównych składników chemicznych minerałów pobocnych lub stanowi domieszkę izomorficzną w ich strukturze, a także tworzy minerały własne. Niewielka zmienność udziału innych pierwiastków barwiących (zwłaszcza z grupy metali przejściowych) przy wyraźnym zróżnicowaniu odcieni i jasności próbek po wypaleniu sugeruje, że jako tego przyczynę należałoby brać pod uwagę nie tylko analityczną zawartość żelaza, ale również stopień jego utlenienia (wartościowość) i pozycję strukturalną (koordynację). Nie stwierdzono bowiem w toku przeprowadzonych badań prostej, jednoznacznej korelacji zawartości $\mathrm{Fe}_{2} \mathrm{O}_{3}$ z parametrami barwy próbek.

Analizując próbki o niemal jednakowym udziale żelaza, a różnej jasności i zabarwieniu, takie jak SI-4 i SI-8 i PW-1 (rys. 13), powzięto przypuszczenie, że to zróżnicowanie może być spowodowane większą zawartością żelaza w postaci minerałów własnych względnie jonów tego pierwiastka o różnej wartościowości zlokalizowanych $\mathrm{w}$ takich pozycjach w strukturze minerałów pobocznych, w których możliwe jest ich wzajemne oddziaływanie.

Według Mac Carthy’ego (1926) barwa minerałów zawierających fazy żelaziste zależy od stosunku $\mathrm{FeO}$ do $\mathrm{Fe}_{2} \mathrm{O}_{3}$, gdyż kationy $\mathrm{Fe}^{3+}$ i $\mathrm{Fe}^{2+}$ zazwyczaj współwystępują obok siebie. Jeśli wartość tego ilorazu jest niższa od 0,5 pojawia się barwa żółta lub czerwona, przy wartości 0,5-9,0 - niebieska, szaroniebieska, zielononiebieska lub zielona, a powyżej 9,0 - czarna.

Późniejsze badania wykazały, że zabarwienie minerałów może być spowodowane przez przejścia elektronowe (typu redox) pomiędzy jonami metalu sąsiadującymi ze sobą w sieci krystalicznej (Sikora 1974; Nassau 1978). Są one szczególnie uprzywilejowane, jeśli dotyczy to jonów tego samego metalu o różnej wartościowości, np. $\mathrm{Fe}^{2+}$ i Fe ${ }^{3+}$. Przejściom elektronowym sprzyja także istnienie lokalnie niezrównoważonych ładunków elektrycznych wynikających z diadochii heterowalentnej (np. podstawień izomorficznych $\mathrm{Fe}^{2+} \mathrm{za} \mathrm{Al}^{3+}$, czy $\mathrm{Mg}^{2+} \mathrm{za} \mathrm{Fe}^{3+}$ ). Oprócz wartościowości na barwę wpływ ma koordynacja jonu, tj. czy znajduje się on w pozycji tetra- czy oktaedrycznej (o liczbie koordynacyjnej odpowiednio 4 i 6). Zagadnienie to najlepiej poznano dla struktur, w których obecne są kationy żelaza. Przejścia elektronów typu redoks mogą zachodzić między jonami $\mathrm{Fe}^{2+}$ i $\mathrm{Fe}^{3+}$ o różnej lub takiej samej liczbie koordynacyjnej. Najczęściej przyczyną barwy minerałów jest oddziaływanie elektronowe $\mathrm{Fe}^{2+}(\mathrm{LK}=6) \rightarrow \mathrm{Fe}^{3+}(\mathrm{LK}=4)$ (Sikora 1974). Badania prowadzone przez Rimską-Korsakovą i Sokolovą (vide Sikora 1974) wykazały, że obecność $\mathrm{Fe}^{3+}$ w pozycji tetraedrycznej znacznie silniej wpływa na zabarwienie minerału niż jego położenie w pozycji oktaedrycznej. Jeżeli wymieniony kation obsadza wyłącznie tę ostatnią, to - niezależnie od proporcji $\mathrm{Fe}^{2+} \mathrm{i} \mathrm{Fe}^{3+}$ - barwa jest zielona. Jeśli jednak nawet niewielka ilość $\mathrm{Fe}^{3+}$ znajdzie się w pozycjach tetraedrycznych - barwa będzie intensywnie czerwonobrunatna (przy tej samej proporcji $\mathrm{Fe}^{2+} \mathrm{i} \mathrm{Fe}^{3+}$ ). Minerały, w których $\mathrm{Fe}^{2+}$ występuje w koordynacji oktaedrycznej $(\mathrm{LK}=6)$ wykazują zabarwienie w odcieniach zieleni i błękitu. 
Znane są również fazy mineralne zawierające $\mathrm{Fe}^{2+}$ o liczbie koordynacyjnej $8 \mathrm{w}$ kolorach różowoczerwonych czy pomarańczowoczerwonych.

W kontekście rozważań na temat barwy wywoływanej przez kationy żelaza w różnych konfiguracjach należy również uwzględnić rolę $\mathrm{TiO}_{2}$. Tlenek ten w czystej postaci nie absorbuje światła $\mathrm{w}$ zakresie widzialnym (dlatego znajduje zastosowanie jako biały pigment). Obecność żelaza w strukturze $\mathrm{TiO}_{2}$ sprzyja przejściom elektronowym $\mathrm{Fe}^{2+} \rightarrow \mathrm{Ti}^{4+}$. Przeprowadzone badania wykazały (Hogg i Noble 1979), że pomiędzy współwystępującymi jonami $\mathrm{Fe}$ i Ti następuje przeniesienie ładunku lub przeskok elektronu, w którym pośredniczy atom tlenu, a mianowicie: $\mathrm{Fe}^{2+}-\mathrm{O}-\mathrm{Ti}^{4+} \rightarrow \mathrm{Fe}^{3+}-\mathrm{O}-\mathrm{Ti}^{+3}$. Przeniesienie ładunku powoduje przesunięcie pasma absorpcji na skraj obszaru widzialnego i bliskiego ultrafioletu. Nawet przy niewielkim udziale żelaza następuje wyraźna zmiana odcienia minerału. Zjawisko to opisano jako titania effect (Weaver 1976; Chyandrasekhar i Ramaswamy 2002). Może to tłumaczyć odmienność odcieni próbek o tej samej zawartości żelaza, a różnej - tytanu (takich jak SI-4 i SI-8, czy PW-1 i SL-2). Przeniesienie ładunku może również mieć miejsce pomiędzy żelazem i jonem jakiegokolwiek innego metalu przejściowego, obecnego w strukturze minerałów pobocznych, umożliwiając absorpcje światła, tym samym powodując zmianę ich zabarwienia.

Wyjaśnienie przyczyny odmiennego zabarwienia próbek o identycznej lub zbliżonej zawartości żelaza oraz natury wzajemnego oddziaływania jonów wybranych pierwiastków w sieci krystalicznej minerałów będących ich nośnikami jest zagadnieniem niezwykle trudnym. Pochodzenie barwy minerałów można m.in. tłumaczyć posługując się jedną z trzech teorii struktury elektronowej ciał stałych: pola krystalicznego, orbitali magnetycznych lub pasmową. Specyficzny efekt kolorystyczny może być również wywołany przez takie zjawiska optyczne, jak rozszczepienie, rozproszenie i interferencja światła.

Wydaje się, że dokładna interpretacja zróżnicowania barwy badanych próbek wymagałaby przede wszystkim zastosowania bardziej zaawansowanych metod badawczych, np. spektroskopii absorpcyjnej EPR, która umożliwia wykrycie i ilościowe oznaczenie zawartości kationów żelaza, głównie $\mathrm{Fe}^{3+}$ (a także innych metali przejściowych i ziem rzadkich) oraz określenie ich pozycji strukturalnych (koordynacji), względnie wykrycie centrów paramagnetycznych, powodujących zabarwienie minerałów, nie zawsze związane z obecnością metali przejściowych lub ziem rzadkich (Dyrek i Żabiński 1988). Na podstawie widm EPR można także wnioskować, czy domieszka metalu przejściowego występuje w sieci krystalicznej czy w postaci submikroskopowych wrostków (np. hematytu w skaleniach potasowych) (Hofmeister i Rossman 1984). Konkludując należy stwierdzić, że obserwowana zmienność odcienia i nasycenia barwy badanych próbek może być wynikiem nie tylko różnej zawartości żelaza, ale odmiennej koordynacji i wartościowości kationów tego pierwiastka w strukturze minerałów, będących jego nośnikami, przy równoczesnej obecności innych metali przejściowych, zwłaszcza tytanu.

Autorka składa podziękowania Zarzqdowi Strzeblowskich Kopalń Surowców Mineralnych Sp. z o.o. oraz Panu dr. hab. Wojciechowi Franusowi z Politechniki Lubelskiej za pomoc w realizacji badań 


\section{LITERATURA}

Bolewski i in. 1991 - Bolewski, A., Budkiewicz, M. i Wyszomirski, P. 1991. Surowce ceramiczne. Warszawa: Wydawnictwa Geologiczne, ss. 397.

Chyandrasekhar, S. i Ramaswamy, S. 2002. Influence of mineral impurities on the properties of kaolin and its thermally treated products. Applied Clay Science 21, 133-142.

Dyrek, K. i Żabiński, W. 1988. Elektronowy rezonans paramagnetyczny [W:] Bolewski A. i Żabiński W. red. Metody badań minerałów i skat. Warszawa: Wydawnictwa Geologiczne, s. 469-488.

Dziubak, C. 2012. Fizykochemiczne podstawy syntezy ceramicznych pigmentów cyrkonowych. Kraków: Ceramika/Ceramics 112 .

Hofmeister, A.M. i Rossman, G.R., 1984. Determination of $\mathrm{Fe}^{3+}$ and $\mathrm{Fe}^{2+}$ concentrations in feldspar by optical absorption and EPR spectroscopy. Physics and Chemistry of Minerals 11/5, s. 213-224.

Hogg, C.S. i Noble, F.R. 1979. A Kubelka-Munk analysis of the influence of iron and titanium oxides on the optical properties of hard porcelain. Science of Ceramics 10. Berchtesgaden/Germany, s. 703-710.

Lewicka, E. 2013. Barwa po wypaleniu a skład mineralny kopalin skaleniowych z rejonu Sobótki. Gospodarka Surowcami Mineralnymi-Mineral Resources Management 29(1), s. 35-51.

Lewicka, E. i Franus, W. 2014. Badania przyczyn niejednorodności surowca skaleniowo-kwarcowego po wypaleniu. Gospodarka Surowcami Mineralnymi - Mineral Resources Management 30(1), s. 69-83.

Mac Carthy, G.R. 1926. Colors produced by iron in minerals and the sediments. American Journal of Science 12 , s. $17-36$.

Mielicki, J. 1997. Zarys wiadomości o barwie. Fundacja Rozwoju Polskiej Kolorystyki, Łódź.

Nassau, K. 1978. The origins of color in minerals. American Mineralogist 63, s. 219-229.

Sikora, W. 1974. Żelazo w kaolinach pierwotnych Dolnego Śląska. Prace mineralogiczne 39. Warszawa: Wydawnictwa Geologiczne, ss. 76.

Weaver, C.E. 1976. The nature of $\mathrm{TiO}_{2}$ in kaolinite. Clays and Clay Minerals 24, s. 215-218.

\section{BADANIE WPEYWU DOMIESZEK ŻELAZA NA CECHY OPTYCZNE KOPALIN SKALENIOWO-KWARCOWYCH PO WYPALENIU}

Słowa kluczowe

parametry barwy $\mathrm{L}^{*} \mathrm{a} \mathrm{b}^{*}$, metale przejściowe, kationy żelaza, pozycja strukturalna

\section{Streszczenie}

Artykuł przedstawia wyniki badań wybranych próbek kopaliny skaleniowo-kwarcowej z czterech złóż granitoidów w rejonie Sobótki: Pagórki Wschodnie, Pagórki Zachodnie, Strzeblów I i Stary Łom. Ich celem było ustalenie przyczyn zróżnicowania zabarwienia próbek o zbliżonym udziale $\mathrm{Fe}_{2} \mathrm{O}_{3}$ po wypaleniu $\mathrm{w} 1200^{\circ} \mathrm{C}$. Charakterystykę mineralogiczną, ze szczególnym uwzględnieniem nośników żelaza i innych pierwiastków barwiących, oraz skróconą analizę składu chemicznego kopalin z wymienionych złóż przeprowadzono w latach 2011-2012. Badania te nie dały jednoznacznej odpowiedzi na temat powodów różnej barwy próbek. Postulowano wówczas wykonanie pełnej analizy chemicznej na zawartość składników głównych oraz pierwiastków śladowych, która potwierdziłaby stawianą wówczas hipotezę o podwyższonym udziale innych niż żelazo pierwiastków barwiących w próbkach, tj. m.in.: Mn, Ce, Th, U, REE. Taka analiza, wraz z bardziej szczegółowymi obserwacjami mikroskopowymi SEM połączonymi z pomiarami składu chemicznego w mikroobszarze (EDS) została przeprowadzona w ramach niniejszej pracy. Mimo, iż badania te wykazały obecność 
metali przejściowych w próbkach, ich zawartość uznano za zbyt małą, by można było wyłącznie z nią wiązać zróżnicowanie barwy. Brak prostej korelacji pomiędzy udziałem żelaza a parametrami barwy „L” i „a” badanych próbek może wskazywać na bardziej złożone przyczyny, tj. różne pozycje strukturalne, wartościowość i koordynację kationów żelaza, przy równoczesnym oddziaływaniu jonów innych metali przejściowych, pierwiastków ziem rzadkich i aktynowców, wykrytych w strukturze minerałów w poszczególnych próbkach. Ich obecność może sprzyjać zjawisku absorpcji, skutkując zmianą barwy.

\section{STUDY OF THE INFLUENCE OF IRON IMPURITIES ON OPTICAL CHARACTERISTICS OF FELDSPAR-QUARTZ RAW MATERIALS AFTER FIRING}

Key words

$\mathrm{L} * \mathrm{a} * \mathrm{~b} *$ colour values, transition elements, iron cations, structural position

Abstract

The article presents the studies of selected feldspar-quartz raw materials coming from four deposits of granitoids located in the Sobótka region, i.e.: Pagórki Wschodnie, Pagórki Zachodnie, Strzeblów I, and Stary Łom. The purpose of the research was to determine the reasons for different colour after firing at $1,200^{\circ} \mathrm{C}$ of samples with a similar content of $\mathrm{Fe}_{2} \mathrm{O}_{3}$. The mineralogical characteristics, with particular regard to carriers of iron and other colouring elements, and shortened analysis of chemical composition of the rocks from above mentioned deposits, were conducted in 2011-2012. Those examinations did not give the unambiguous explanation of the reasons for various colours of the samples. Therefore, there was suggested to perform a full chemical analysis on the content of major and trace elements, which could confirm a hypothesis of a higher share of other than iron colouring elements in the samples, including: $\mathrm{Mn}, \mathrm{Ce}, \mathrm{Th}, \mathrm{U}$, and REE. Such an analysis, together with detailed observations in scanning electron microscope (SEM) coupled with measurements by microprobe (EDS) has been performed within the framework of the presented work. Although these studies have shown the presence of transition metals in the samples, however their low contents cannot explain the differentiation in colour. Lack of direct correlation between the quantity of iron present and "L" and "a" colour parameters of the samples may indicate more complex reasons of this phenomenon, i.e. different structural position, valence and coordination, in which iron cations occur in each sample, which can be simultaneously affected by ions of transition metals, rare earths and actinides, detected in the structure of minerals in individual samples. Their presence can promote the phenomenon of absorption resulting in a colour change. 